\title{
APLIKASI PROBIOTIK DALAM PAKAN SIDAT (Anguilla bicolor) TERHADAP BAKTERI PATOGEN Aeromonas sp.
}

\author{
Khansa Biantari Alika ${ }^{1}$, Geovanni Pratama Putri ${ }^{2}$, Khadafiah Mutia Wiandari ${ }^{3}$, \\ Diah Kusumawaty ${ }^{4 *}$ \\ 1, 2, 3,4 Program Studi Biologi, Fakultas Pendidikan Matematika dan Ilmu Pengetahuan Alam \\ Universitas Pendidikan Indonesia \\ *e-mail: diah.kusumawaty@upi.edu
}

\begin{abstract}
Anguilla bicolor bicolor is one of the types of eel in Indonesian waters, because of its high selling value, it is one of the potential fishery commodities so that it becomes the leading product of Indonesian fishery exports in the international market. In eel cultivation, seed maintenance and maintenance at each turn of the stage is a crucial stage that must be considered. The growth stages of eels are divided into three, namely 1) Glass eel, 2) Elver, 3) Fingerling. In this study, the data is obtained using secondary data and the results of the data were analyzed descriptively. The results of the three stages showed the abundance of various probiotic and pathogenic bacteria. The results of metagenomic studies can provide data, one of which is to determine the relative abundance of probiotic bacteria and pathogenic bacteria at the developmental stage of eel.
\end{abstract}

Keywords: Eel, probiotic, pathogen, abundance, fish feed

\begin{abstract}
ABSTRAK
Anguilla bicolor bicolor merupakan salah satu jenis ikan sidat yang ada di perairan Indonesia, karena nilai jualnya yang tinggi menjadi salah satu komoditas perikanan yang potensial sehingga menjadi produk unggulan ekspor perikanan Indonesia di pasar internasional. Pada budidaya sidat, pemeliharaan benih dan pemeliharaan pada setiap pergantian tahapan merupakan tahap krusial yang harus diperhatikan. Tahap pertumbuhan ikan sidat terbagi menjadi tiga yaitu 1) Glass eel, 2) Elver, 3) Fingerling. Pada penelitian ini diperoleh menggunakan data sekunder dan hasil data dianalisis dengan cara deskriptif. Hasil penelitian pada ketiga tahap menunjukkan kelimpahan bakteri probiotik dan patogen yang beragam. Hasil studi metagenomik dapat menyediakan data salah satunya untuk mengetahui kelimpahan relatif bakteri probiotik dan bakteri patogen pada tahap perkembangan ikan sidat.
\end{abstract}

Kata kunci: Ikan sidat, probiotik, patogen, kelimpahan, pakan ikan

\section{PENDAHULUAN}

Anguilla bicolor bicolor merupakan salah satu jenis ikan sidat yang ada di perairan Indonesia, karena nilai jualnya yang tinggi menjadi salah satu komoditas perikanan yang potensial sehingga menjadi produk unggulan ekspor perikanan 

Mutia Wiandari, Diah Kusumawaty, Indobiosains, Volume 3 No. 2, Agustus 2021, 1-8.

Indonesia di pasar internasional. Tingginya permintaan sidat di pasar internasional berbanding terbalik dengan produksi sidat di Indonesia. Faktor-faktor yang berkontribusi dalam penurunan keberadaan sidat liar diantaranya dapat meliputi penangkapan ikan berleihan, hilangnya habitat, hambatan migrasi dan polusi kimia atau kombinasi dari seluruh faktor tersebut.

Oleh karena itu, mulai dikembangkan budidaya ikan sidat dengan mengambil benih dari alam yang kemudian dibesarkan di kolam-kolam pemeliharan. Dalam sistem budidaya sidat, penyakit merupakan faktor penting yang membatasi pertumbuhan. Penyakit yang berkembang dalam budidaya ikan sidat sebagian besar disebabkan oleh kehadiran bakteri oportunistik yang tumbuh baik dalam medium lingkungan air akibat penggunaan pakan berlebih serta padat tebar yang tinggi (Chinabut dan Puttinaowarat 2005).

Pada budidaya sidat, pemeliharaan benih dan pemeliharaan pada setiap pergantian tahapan merupakan tahap krusial yang harus diperhatikan. Tahap pertumbuhan ikan sidat terbagi menjadi tiga, yaitu: 1) Glass eel atau benih berukuran 0,2 g/ekor yang dibudidayakan hingga ukuran 2-3 g/ekor selama 2-3 bulan sehingga dihasilkan tahap elver; 2) Elver yang berukuran 3 g/ekor yang dibudidayakan selama 3-4 bulan sehingga diperoleh ikan sidat tahap elver dengan ukuran mencapai 10 g/ekor; 3) Fingerling merupakan ikan sidat elver yang telah melalui proses pemeliharaan selama 3-4 bulan dan hingga beratnya mencapai 20-50 g/ekor; 4) Tahap terakhir yaitu pembesaran selama 4-6 bulan hingga ukuran mencapai lebih dari 200 g/ekor (Suitha, 2008).

Komunitas bakteri (mikrobiota) pada hewan akuatik bersifat dinamis mengikuti komunitas bakteri di lingkungannya serta berpengaruh terhadap pertumbuhan dan kemampuan bertahan hidup. Bakteri berperan dalam mencegah bakteri patogen oportunis untuk berproliferasi dan mengkolonisasi tubuh inang, terutama pada tahap larva di mana sistem imunitas belum berkembang sempurna (Hansen dan Olafsen, 1999).

Peningkatkan kelulushidupan dan produktivitas dengan mencegah penyakit dapat dilakukan secara aman dengan introduksi bakteri yang menguntungkan yaitu bakteri probiotik ke dalam komunitas bakteri yang telah terbentuk pada inang. Hubungan antara mikroba dan inangnya yang bersifat dinamis menyebabkan variabilitas bakteri intestinal sehingga mengindikasikan kepentingan bertujuan untuk mengembangkan probiotik dalam pemanfaatan pakan pada setiap tahapan budidaya ikan sidat yaitu glass eel, elver dan fingerling.

\section{METODE PENELITIAN}

Penelitian dilakukan menggunakan data sekunder berdasarkan studi yang telah dilakukan oleh Kusumawaty $d k k$., (2020) berjudul "Data on Community Structure and Diversity of the Intestinal Bacteria in Elver and Fingerling Stage of Wild Indonesian Shortfin Eel (Anguilla bicolor bicolor)."

Data sekunder yang diperoleh kemudian dianalisis secara deskriptif dan karakterisasi bakteri probiotik serta patogen dilakukan berdasarkan studi literatur dengan penelusuran dari berbagai sumber baik jurnal nasional maupun internasional.

\section{HASIL DAN PEMBAHASAN}

Perkembangan produksi ikan sidat dapat memicu serangan penyakit akibat interaksi yang tidak seimbang antara inang, patogen dan lingkungan. Interaksi yang tidak seimbang tersebut mengakibatkan stres pada ikan sehingga melemahkan 
mekanisme pertahanan diri dan penyakit dapat menyerang ikan. Beberapa penelitian sebelumnya menunjukkan bahwa penyakit yang biasanya menyerang ikan sidat diakibatkan oleh bakteri. Berdasarkan penelitian yang dilakukan oleh Wahjuningrum dkk., (2018), A. hydrophila dan S. agalactiae adalah bakteri penyebab penyakit pada Anguilla bicolor bicolor. Aeromonas hydrophila adalah perwakilan Aeromonas yang paling umum ditemukan di air, hewan peliharaan dan makanan (ikan, kerang, unggas dan daging mentah).

Peningkatan kejadian penyakit pada ikan, manusia dan hewan dapat disebabkan oleh Aeromonas sp. termasuk Aeromonas hydrophila. Bakteri patogen tersebut dikenali menyebabkan penyakit pada banyak spesies ikan termasuk belut dan spesies kerang (Yousr et.al., 2007; Sharma et.al., 2009). Dalam penelitian Joh et.al. (2010) di Korea pada Anguilla japonica juga dilaporkan bahwa bakteri patogen yang menyerang berasal dari genus Aeromonas yaitu Aeromonas hydrophila, Aeromonas salmonicida dan Aeromonas veronii. Beberapa galur Aeromonas telah terbukti bersifat patogen pada sidat (Yi et.al, 2013). Hal ini menunjukkan bahwa bakteri patogen berpotensi menyebabkan penyakit pada ikan sidat.

Peningkatan tingkat nutrisi dan tingkat kekebalan hewan budidaya terhadap mikroorganisme patogen dapat diperoleh melalui penggunaan probiotik. Probiotik merupakan sejumlah bakteri yang ditambahkan dan memiliki efek menguntungkan karena dapat memperbaiki keseimbangan komposisi mikroflora usus dan mendukung kesehatan inang. Selain itu, hal tersebut dapat mengurangi penggunaan antibiotik dan berjangkitnya penyakit dapat dicegah.

Berdasarkan cara kerjanya, probiotik dapat dibagi menjadi dua kategori besar: (a) probiotik usus: yang diberikan secara oral bersama dengan makanan untuk meningkatkan flora mikroba menguntungkan pada pencernaan dan (b) probiotik air: berkembang biak dalam media air dan mengeluarkan bakteri patogen dari media tertentu dengan mengkonsumsi semua nutrisi yang tersedia.

Probiotik memainkan peran penting dalam menjaga kesehatan usus dengan modulasi struktur komunitas mikroba. Mikroorganisme probiotik memiliki efek menguntungkan yaitu dalam proses pencernaan nutrisi makanan pada usus hewan akuatik dengan merangsang penyerapan nutrisi melalui peningkatan luas permukaan usus.

Pemanfaatan probiotik pada media dapat menghambat berkembangnya organisme patogen dan mengatasi infeksi pada benih ikan dimana merupakan tahap krusial dalam budidaya ikan sidat (Itoh et.al, 1995). Penggunaan probiotik bermanfaat dalam meningkatkan kualitas lingkungan perairan dengan mengurangi angka kematian yang ditunjukkan oleh Omenwa et.al. (2015) bahwa Lactobacillus pada ikan mampu menaikkan tingkat kelulushidupan menjadi 96,22\%. Dalam berbagai penelitian juga didapatkan bakteribakteri probiotik yang sudah diketahui manfaatnya pada beberapa ikann. (Tabel 1.)

Berdasarkan studi penelitian pada komposisi bakteri di ikan sidat, didapatkan beberapa kandidat bakteri probiotik yang terdiri dari bakteri asam laktat (BAL), Bifidobacterium dan Streptococcus, Bacillus subtilis, Lactobacillus helveticus, Enterococcus faecium, Carnobacterium inhibens, dll. (Giri et.al., 2013; Lakshmi et.al, 2013). Bakteri probiotik tersebut ditemukan dalam data sekunder yang diperoleh dari studi metagenomik oleh Kusumawaty dkk. (2020) dengan komposisi yang tertera pada grafik. (Grafik 1.)

Pada tahap pertama yaitu eel cultivated didominasi oleh bakteri 
Carnobacterium, selanjutnya pada tahap kedua yaitu fingerling wild didominasi oleh bakteri Lactobacillus pada urutan pertama selanjutnya pada urutan kedua yaitu bakteri Enterococcus. Pada tahap ketiga yaitu tahap terakhir elver wild didominasi oleh bakteri Lactococcus pada urutan pertama selanjutnya pada urutan kedua yaitu bakteri Enterococcus.

Keberadaan Aeromonas dapat menjadi indikasi bahwa terdapatnya bakteri patogen. Bakteri probiotik Bacillus merupakan bakteri probiotik yang mampu menghambat pertumbuhan bakteri patogen, Aeromonas sp. Kemampuan penghambatan probiotik Lactococcus lactis RQ516 terhadap A. hydrophila telah ditunjukkan oleh Zhou et.al. (2010) secara in vitro, selain itu Salini et.al. (2013) mengamati bahwa keragaman dan intensitas flora mikroba berkurang ketika diperlakukan dengan kultur diet obat yang mengandung bakteri probiotik Bacillus. Bakteri probiotik yang di uji dengan bakteri patogen membentuk hambatan, artinya bakteri probiotik tersebut menghasilkan produk antibiotik, bakteriosin, ataupun asam organik tertentu. Agen antibakteri seperti asam laktat dan bakteriosin yang dimiliki bakteri probiotik dapat menghambat pertumbuhan bakteri patogen. Hal ini dikarenakan agen antibakteri mampu menurunkan $\mathrm{pH}$ menjadi rendah sehingga bakteri patogen sulit bertahan hidup (Tambekar and Bhutada, 2010).

Pembatasan penggunaan antibiotik pada ikan budidaya dan potensi dampak negatifnya terhadap kesehatan masyarakat dan lingkungan memerlukan evaluasi mengenai jalan alternatif. Penggunaan probiotik bersama dengan suplemen makanan adalah strategi yang sangat bermanfaat untuk memerangi agen patogen melalui berbagai mekanisme sebagai kekuatan pendorong alternatif pengobatan antibiotik.

Tabel 1. Jenis Bakteri Probiotik dan Manfaatnya

\begin{tabular}{|c|c|c|}
\hline Jenis probiotik & Manfaat & Referensi \\
\hline Lactobacillus rhamnosus & $\begin{array}{l}\text { Meningkatkan kekebalan dan } \\
\text { mengurangi kerentanan penyakit }\end{array}$ & Nikoskelainen et.al.(2003) \\
\hline Lactobacillus plantarum & $\begin{array}{l}\text { Meningkatkan toleransi terhadap } \\
\text { stress }\end{array}$ & Taoka et.al. (2008) \\
\hline Lactobacillus rhamnosus & Meningkatkan kualitas darah & Panigrahi et.al. (2010) \\
\hline Bacillus subtilis & Meningkatkan imunitas seluler & Sánchez-Ortiz et.al. (2015 \\
\hline Bacillus amyloliquefaciens & $\begin{array}{l}\text { Meningkatkan konsentrasi } \\
\text { antibodi, mengurangi stres }\end{array}$ & Nandi et.al. (2018) \\
\hline Lactobacillus sp. & $\begin{array}{l}\text { Mengurangi beban patogen, } \\
\text { memberikan perlindungan } \\
\text { terhadap Aeromonas hydrophila }\end{array}$ & He et.al. (2017) \\
\hline
\end{tabular}




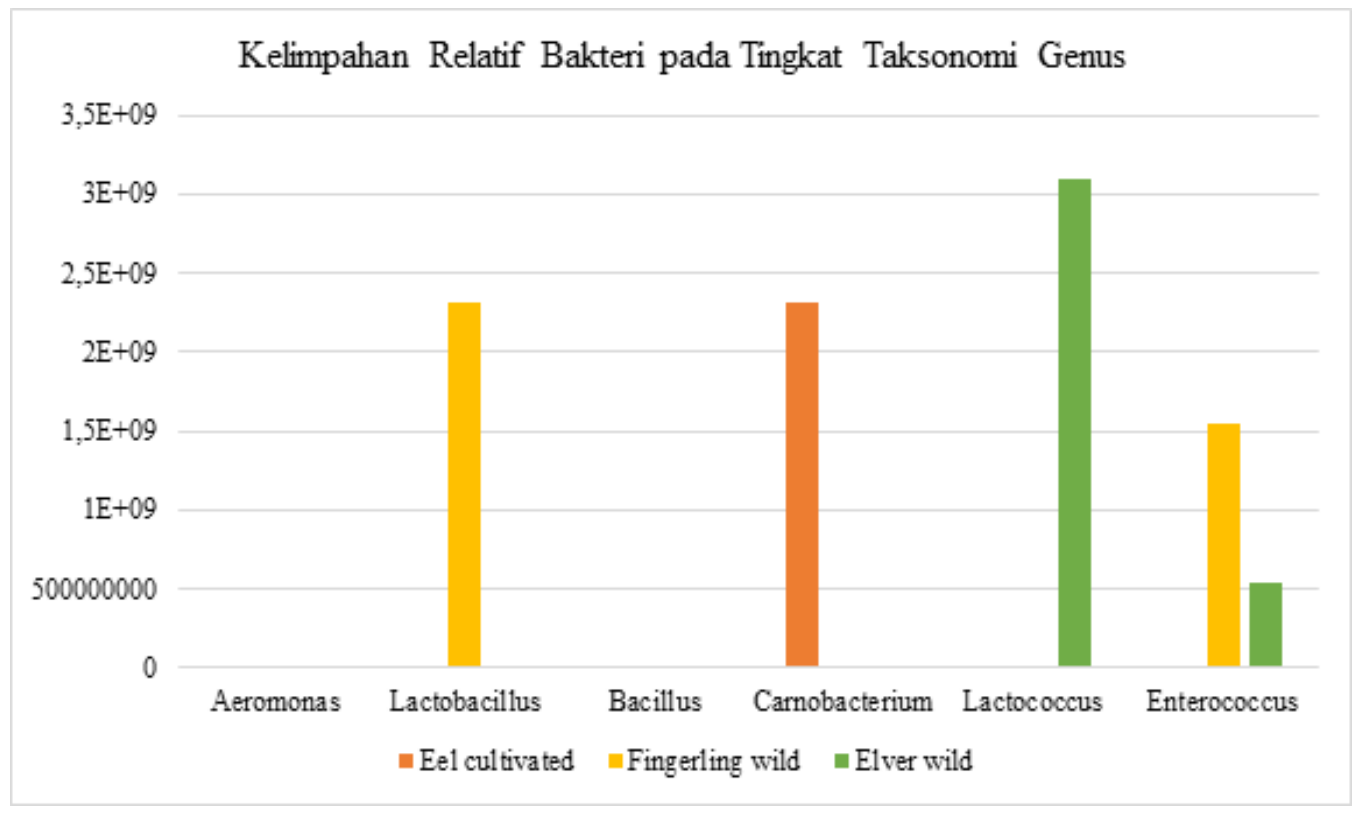

Grafik 1. Kelimpahan Relatif Bakteri pada Ketiga Tahap Ikan Sidat

Terlepas dari probiotik berbasis laboratorium yang telah didapatkan dan dibahas, berbagai probiotik komersial yang disetujui secara eksperimental dan efektif dalam akuakultur tersedia di pasar yang juga diantaranya Lact-Act Geomarine berasal dari Lactobacillus sporogens yang diproduksi oleh Biotechnologies serta Biotix Plus Matrix yang memanfaatkan Lactobacillus sp. dan diproduksi oleh Biosciences.

Percobaan skala penuh kandidat probiotik sebagai pakan dalam berbagai tahapan ikan sidat penting untuk dikomersilkan di pasaran dengan memenuhi kriteria pemilihan probiotik diantaranya tidak berbahaya bagi inang, bersifat noninvasif dan non-karsinogenik, dapat menjangkau secara efektif di situs target inang, mengandung plasmid tanpa gen resistensi antibiotik dan virulensi, telah diketahui efeknya untuk jangka waktu yang stabil dan bereplikasi di dalam tubuh inang dan harus benar-benar bekerja dalam sistem model inang yang dapat dibuktikan dengan temuan in vitro.

\section{KESIMPULAN}

Hasil studi metagenomik dapat menyediakan data salah satunya untuk mengetahui kelimpahan relatif bakteri probiotik diantaranya Lactobacillus, Bacillus, Carnobacterium, Lactococcus dan Enterococcus serta bakteri patogen pada tahap perkembangan ikan sidat sehingga mencegah infeksi penyakit, meningkatkan tingkat kelulushidupan dan produktivitas terhadap bakteri patogen Aeromonas hydrophila melalui utilisasi pakan ikan.

\section{DAFTAR PUSTAKA}

Chinabut, S. dan Puttinaowarat, S. 2005. The choice of disease control strategies to secure international market access for aquaculture product. Dev Biol, 121, 255-261. 

Mutia Wiandari, Diah Kusumawaty, Indobiosains, Volume 3 No. 2, Agustus 2021, 1-8.

Dahiya, T. 2012. Elimination of pathogenic bacterium, Aeromonas hydrophila by the use of probiotics. Journal of FisheriesSciences.Com, 6(3), 209214.

Dewi, N. dan Koesharyani, I. 2017. Studies on Aeromonas hydrophila bacteria diseases in wild and cultured elver eel (Anguilla bicolor). Indonesian Aquaculture Journal, 12(2), 77.

Giri, S. S., Sukumaran, V. dan Oviya, M. 2013. Potential probiotic Lactobacillus plantarum VSG3 improves the growth, immunity, and disease resistance of tropical freshwater fish, Labeo rohita. Fish and Shellfish Immunology, 34(2), 660-666.

Hansen, G.H. dan Olafsen, J.H. 1999. Bacterial interaction in early life stages of marine cold water fish. Microb Ecol, 38, 1-26.

Hasan, K. N. dan Banerjee, G. 2020. Recent studies on probiotics as beneficial mediator in aquaculture: a review. The Journal of Basic and Applied Zoology, 81(1).

He, S., Ran, C., Qin, C., Li, S., Zhang, H., de Vos, W. M., ... Zhou, Z. 2017. Anti-infective effect of adhesive probiotic Lactobacillus in fish is correlated with their spatial distribution in the intestinal tissue. Scientific Reports, 7(1), 13195.

Itoh, T., Fujimoto, T., Kawai Y., Toba T. dan Saito T. 1995. Inhibition of food borne pathogenic bacteria by bacteriocins from Lactobacillus gasseri. Letters in Applied Microbiology, 21, 137-141.
Joh, S.J., Ahan, E.H., Lee, H.J., Shin, G.W., Kwon, J.H. dan Park, C.G. 2013. Bacterial pathogens and flora isolated from farm-cultured eels Anguilla japonica and their environmental waters in Korean eel farms. Journal Veterinary Microbiology, 163, 190-195.

Kusumawaty, D., Surtikanti, H. K., Hernawati dan Tallei, T. E. 2020. Data on community structure and diversity of the intestinal bacteria in elver and fingerling stages of wild Indonesian shortfin eel (Anguilla bicolor bicolor). Data in Brief, 29, 105299.

Lakshmi, B., Viswanath, B. dan Sai Gopal, D. V. 2013. Probiotics as antiviral agents in shrimp aquaculture. Journal of Pathogens, 424123.

Lestari, N. W. dan Budiharjo, A. 2016. Bakteri heterotrof aerobik asal saluran pencernaan ikan sidat (Anguilla bicolor bicolor) dan potensinya sebagai probiotik. Bioteknologi, 13(1), 9-17.

Nandi, A., Banerjee, G., Dan, S. K., Ghosh, K. dan Ray, A. K. 2018. Evaluation of in vivo probiotic efficiency of Bacillus amyloliquefaciens in Labeo rohita challenged by pathogenic strain of Aeromonas hydrophila MTCC 1739. Probiotics and Antimicrobial Proteins, 10(2), 391398.

Omenwa, V.C., Mbakwem-Aniebo, C. dan Ibiene, A.A. 2015. Effects of selected probiotics on the growth and survival of fry-fingerlings of Clarias gariepinus. Journal of 
Pharmacy and Biological Sciences, 10, 89-93.

Panigrahi, A., Kiron, V., Satoh, S., dan Watanabe, T. 2010. Probiotic bacteria Lactobacillus rhamnosus influences the blood profile in rainbow trout Oncorhynchus mykiss (Walbaum). Fish Physiology and Biochemistry, 36(4), 969-977.

Salini, M.P., Thomas, A.A. dan Anand, J. 2013. Alterations in the microbial load at certain alterations in the microbial load at certain nonspecific immune sites of Macrobrachium rosenbergii supplemented with Centella asiatica. The Bioscan, 8(2), 701704.

Sánchez-Ortiz, A. C., Luna-González, A., Campa-Córdova, A. I., EscamillaMontes, R., Flores-Miranda, M. D. C. dan Mazón-Suástegui, J. M. 2015. Isolation and characterization of potential probiotic bacteria from pustulose ark (Anadara tuberculosa) suitable for shrimp farming. Latin American Journal of Aquatic Research, 43(1), 123-136.

Sharma, I., Kumar, A. dan Pramanik, A.K. 2009. Review of techniques on isolation and identification of Aeromonas from the food of animal and fish origin. Assam University Journal of Science \& Technology: Biological Sciences, 4(1), 73-85.

Soeprijanto, A., Guntur dan Fakhri, M. 2018. Aplikasi probiotik dan pakan fermentasi pada pendederan sidat (Anguilla bicolor). Jurnal Perikanan Universitas Gadjah Mada, 20(1), 1922.
Suitha dan I.M. 2008. Teknik Pendederan Elver/Glass Eel Ikan Sidat. Makalah yang Disampaikan dalam Seminar Indonesian Aquaculture 2008 pada Tanggal 17-20 November di Inna Grand Hotel, Yogyakarta. Departemen Kelautan dan Perikanan, Indonesia.

Tambekar, D.H., and Bhutada, S.A. 2010. An evaluation of probiotic potential of Lactobacillus sp. From milk of domestic animals and commercial available probiotic preparations in prevention of enteric bacterial infections. Recent Research Science and Technology, 2(10), 82-88.

Taoka, Y., Yuge, K., Maeda, H., dan Koshio, S. 2008. The efficiency of Lactobacillus plantarum in diet for juvenile Japanese flounder Paralichthys olivaceus reared in a closed recirculating system. Aquaculture Science, 56(2), 193202.

Wahjuningrum, D., Hidayat, A. M. dan Budiardi, T. 2018. Characterization of pathogenic bacteria in eel Anguilla bicolor bicolor. Jurnal Akuakultur Indonesia, 17(1), 94.

Yi, S.W., You, M.J., Cho, H.S., Lee, S.S., Kwon, J.K. dan Shin, G.W. 2013. Molecular characterization of Aeromonas species isolated from farmed eels Anguilla japonica. Journal Veterinary Microbiology, 164, 195-200.

Yousr, A.H., Napis, S., Rusul, G.R.A. dan Son, R. 2007. Detection of aerolysin and hemolysin genes in Aeromonas spp. isolated from environmental 

Mutia Wiandari, Diah Kusumawaty, Indobiosains, Volume 3 No. 2, Agustus 2021, 1-8.

and shellfish sources by polymerase chain reaction. ASEAN Food Journal, 14(2), 115-122.

Zhou, X., Wang, Y., Yao, J. dan Li, W. 2010. Inhibition ability of probiotic, Lactococcuslactis, against A. hydrophila and study of its immunostimulatory effect in tilapia (Oreochromis niloticus). Int $J$ Engineer Sci Tech, 7(2), 73-80. 